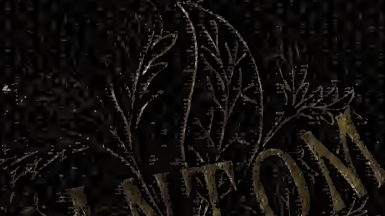

af.
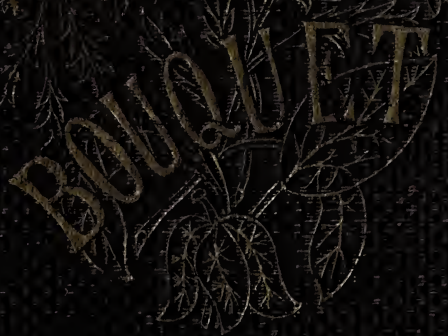


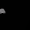



Digitized by the Internet Archive in 2017 with funding from Getty Research Institute 
THE

\title{
PHANTOM BOUQUET:
}

A POPULAR TREATISE ON THE ART OF

\section{SKELETONIZING}

\section{LEAVES AND SEED-VESSELS}

\author{
AND ADAPTING TIIEM TO
}

(Embellish the gome of Taste.

BY

\section{EDWARD PARRISH,}

MEMBER OF THE ACADEMY OF NATURAL SCIENCES OF PHILADELPHIa, the philadelphia college of pharmacy, etc.

\section{PHILADELPHIA :}

J. B. LIPPINCOTT\& CO.

LONDON: ALFRED BENNET.

1864. 
Entered according to Act of Congress, in the year 1862, by EDWARD PARRISII, in the Clerk's Office of the District Court of the United States for the Eastern District of Peunsylvania. 


\section{Too cittu oịlife,}

$\mathbf{A}$

\section{PIONEER AND PROFICIENT}

IN

TIIE ART HEREIN PORTRAYED,

TIIS WORK IS AFFECTIONATELY INSCRIBED. 


\section{PREFACE.}

THIs essay was written in the autumn of 1861 for the Atlantic Monthly, and accepted for publication by the editors of that popular Magazine; but the pressure upon its pages has prevented the appearance of an article which is so little in accordance with the tone of the current American literature during the past eventful year. The numerous applications to the author for instructions in the art of Skeletonizing have induced the determination to delay its publication no longer, and to change it from a magazine article to a small practical work, adapted to aid the tyro in attaining a perfect acquaintance with the subject of which it treats. It is hardly necessary to acknowledge the aid derived from numerous friends of both sexes, who have freely imparted the results of their experience in the matter in hand. Of course, all skeletonizers have learned by this time that it is only by communicating what they know that they can expect to receive in turn the ideas of others, and thus promote our beautiful pursuit to its true position among the liberal arts. 


\section{THE PHANTOM BOUQUET.}

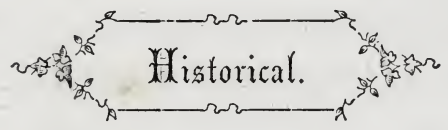

(a) OME years ago the writer was attracted (@) by a beautiful vase of prepared leaves . e? veinings of these plant-structures deprived of their grosser particles, and of such brilliant whiteness as to suggest the idea of perfectlybleached artificial lace-work or exquisite carvings in ivory. This elegant parlor ornament was brought by returning travellers as a novel and choice trophy of their transatlantic wanderings: none could be procured in America, and no one to whom the perplexed admirer could appeal was able to give a clue to the process by which such surprising beauty and perfection of detail could be 
evolved from structures which generally rank among the least admired expansions of the tissue of the plant.

That the novelty of this spectacle then constituted one of its attractions need not be denied; for who that has learned to dwell familiarly on any object of unusual beauty, but can still recall the emotions of delight it created when for the first time it attracted the unaccustomed eye? Yet the "Phantom Case," now that hundreds of pier-tables and étagères in city and country are garnished with its airy forms, and its photographic miniature, under the well-chosen motto, "Beautiful in death," is displayed in almost every stereoscope, still delights with a perennial charm, creating a desire, among all amateurs in matters of taste, to add an ornament so chaste to their household treasures. To this end, an unpretending though sincere lover of nature proposes to lay before his fellows of that genial fraternity which knows neither sex nor nation, a simple and easy 
art, which, while it will prove a pleasurable addition to the arcana of home-occupations, will in its results add to the tasteful embelishments of the household.

Reader, suppose not that this elegant art for which we have no more elegant name than Skeletonizing, is any thing new under the sun. Place it rather among the lost arts revived; for among the quaint old curiosities to be found in the houses of retired sea-captains and East India traders you will often find Chinese pictures, sometimes of considerable beauty and ingenuity, exhibiting flowers, fruit, shells, birds, or insects painted in bright colors on veritable skeleton leaves. Moreover, some of the old London books we have lately forgotten to read give accounts of the identical process, and tell us that, as long ago as 1645, Marcus Aurelius Severinus, professor of anatomy and surgery at Naples, turned his attention to the subject, and published a figure of a leaf thus delicately prepared. But this ingenious disciple of Asculapius, accord- 
ing to the fashion of his time, kept the process a secret, and so we owe probably the first published account of the method of preparing plant-skeletons to a Dutch naturalist, Fredrick Ruysch by name, who in 1723 first gave to the world the announcement that, through the putrefactive fermentation promoted by warmth and moisture, the pulpy matter of the leaf may be loosened so as to be separated from the fibrous skeleton, which may thus be preserved unimpaired. This, reader, is the secret which has for the past year attracted so much attention in the neighborhood of Philadelphia : it was at first communicated in under-tones by certain confidential lady amateurs to their amateur friends, with scrupulous injunctions of secrecy; but now many observations and experiences have been exchanged, and in this charmed circle the new art has attained to greater perfection than could have been expected in a single season.

An incidental but important result of the cultivation of this elegant pursuit is an 
increased attention to leaves. Many to whom a leaf was formerly an object of not the least interest, except perhaps in its connection with the beauty and effect of the shade-tree, or as adding to the variety of the landscape, now eagerly examine it in detail, with reference to its adaptation to the phantom case, and study its outline, whether serrated or entire on its margin, divided, lanceolate, ovate, acuminate, cordate, or irregular in shape. Ferns and lycopods are carefully searched for, with a similar end in view; and, strange to say, the somewhat unsightly burs, the persistent calyxes, and dry and indurated seed-vessels of our wayside weeds, are invested with a new interest by their suspected or ascertained fitness for projected skeleton cases. Since the past summer, hundreds of these have been made tributary to the most chaste and refined ornamentation. 


\section{Something of stieme.}

Wiтhоuт inflicting on the reader a misplaced disquisition on Botany, or its correlative science, Vegetable Physiology, it may be here explained that the leaf, considered in its physiological relations, is to the plant what the digestive and breathing organs are to the animal. Its porous structure permits it to be permeated by moisture drawn up from the soil through the root and stem, and also by the air in which it so incessantly vibrates. These elements, charged with vrinciples adapted to the nutriment of the plant, meet in the leaf-tissue, where they are metamorphosed into the true elements of growth, and elaborated into new cells fitted to develop and increase the living and growing plant. By what subtle influences the sun's ray, acting on these gaseous and liquid particles, works to such marvellous ends, 
producing the innumerable vegetable forms, from the slender grass to the massive oak, and all the infinite variety of fruits of the field and flowers of the meadow and garden, Science has in vain sought to answer. Only the microscope, through its mysterious revealings, points to the cell as the initial, almost infinitely minute, alembic in which this inscrutable and beneficent synthesis is ever going on.

What the older botanists were wont to call nerves, but the modern have named veins, are spread more thoroughly over the leaf than would appear from an examination of the surfaces: in fact, the loosely distributed cellular tissue is everywhere traversed by these ducts, conveying the sap to the extremities, there to be subjected to the subtle chemistry of the cell. The mode of distribution of these veins is one of the leading characteristics observed in the classification of plants. The two great divisions of Endogens and Exogens, having distinct methods of 
growth and distinct structure of the seeds, differ by a distribution in the one case of the veins in curved lines from the origin to the apex of the leaf, while in the other and far more numerous and important class they diverge for the most part at regular angles from a central stem, called the midrib, to the margin.* That this distinction is not artificial, or invented to detract unnecessarily from the uninterrupted gradations of plantstructure, will be apparent to any observer who will take note of the peculiarities of each of these great classes. To the skeletonizer it will be interesting to know that very few of the Endogens have firm enough structure in their veinings to furnish specimens for his art: only two or three are known to the writer, of which the common climbing green brier (Smilax rotundifolia) and wild yam (Dioscorea villosa) are the most familiar.

* See figures 1 and 2. 
Fia. 1

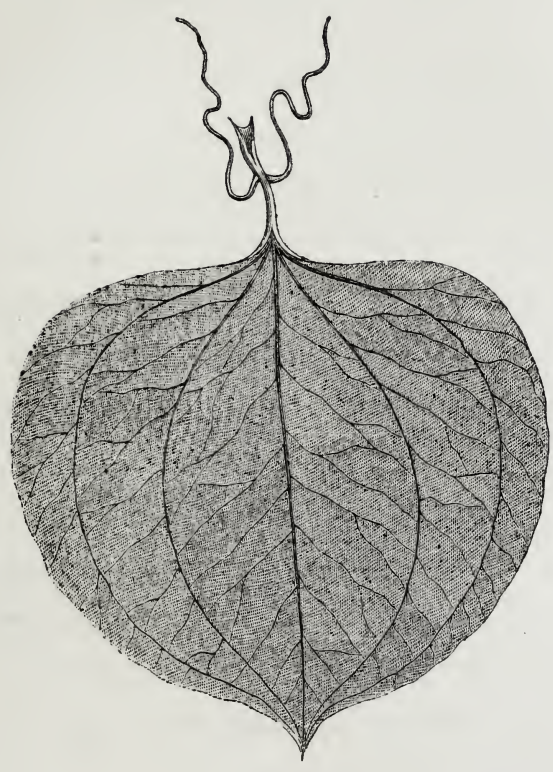

GRERN BRIar LTaF, the under surface, showing the venation of an endogenous leaf. 



\section{Ehe}

THE veinings of the leaf exhibit striking evidence of that unity of design, combined with special adaptations, displayed in every department of nature.

What the trunk and branches are to the tree, are the veins to the exogenous leaf. By continuity and compactness of structure, the delicate spiral fibres which constitute the veins are endowed with strength and elasticity adapting them to sustain and supply the loose tissue which fills up the interstices between them, while, obeying the primal law of growth stamped upon the parent tree, each separate leaf spreads its continuous skeleton into a flattened outline of the tree itself.

A glance at the well-developed tree by twilight, stripped of its leaves, with nothing to obstruct its figure against the sky, will 
scarcely fail to recall, to one accustomed to observe and to compare, the general outline and arrangement of the skeleton leaf. Nor is this a mere fancied resemblance. Dr. McCosh, of the Queen's University, Ireland, in his comprehensive work on "Typical Forms and Special Ends in Creation," has demonstrated the correspondence between the disposition and distribution of the branches of the tree and of the leaf-veins. The very angles at which the branches leave the trunk are shown to correspond in many individual cases with those formed by the lateral veins and midrib upon the leaf; and even the curves which give grace and contour to the tree are repeated among the veins which permeate its leaves. This is believed to be a great natural law throughout the almost infinite variety of vegetable forms.

We rarely see trees which have not been somewhat changed from their normal mode of growth by prevailing winds, or too partial sunlight, or by cattle browsing on them, or 
man pruning or otherwise mutilating them: yet so far as the true pattern of the whole plant has been studied, it is found to correspond beautifully with that of its every single leaf.

Observe, also, how often the length of the petiole, or leaf-stalk, has a direct relation to the height reached by the stem in its unobstructed growth before branches strike off from it. In the case of the box, the privet, the laurel, the snowberry, and other favorite lawn or hedge plants, and the oak, the elm, the beech, and some other common foresttrees, which when unpruned incline to send out branches from the very base, the leaf, in botanical language, is almost sessile, sitting directly upon the stem; while those which have naturally a bare trunk, such as the cherry, the apple, the pear, the chestnut, the poplar, and, above all, our splendid American tulip poplar tree, have leaf-stalks of greater length, sometimes exceeding that of the leaf itself. 
Without designing to pursue this somewhat abstruse subject farther than will suffice to vindicate its interest and importance and lead the amateurs of our art to trace out these relations for themselves, it will suffice, in conclusion, to direct attention to a peculiarity in the arrangement of certain divided and compound leaves, which accords beautifully with the idea we have been attempting to illustrate.

Our familiar sycamore or buttonwood tree has a very characteristic growth. Its bare trunk, rising eight or ten feet from the ground, commonly divides itself at once into four or five branches of great length, the whole aspect of the tree in its branching and leafage being loose and open; so its leaf, branching out from a long foot-stalk, is sustained by five midribs, the intervening structure being extremely delicate, so much so that no skeletonizer with whom I am acquainted has succeeded in separating and preserving it. The horse-chestnut presents a 
similar instance. The seven branches into which its leaf-stalk divides, constituting as many separate leaflets, follow the same type as the perfect tree which spreads from the top of its bare trunk a whorl of ascending and spreading branches.

Reader, we may now be charged with having trenched somewhat upon the domain of the imagination; and if the stern logic of unexplained or conflicting facts is brought in contact with these inspiring ideas, sustained as they are by many observations of undoubted import, let us not contend, but, rather confess that, like all human strivings after the archetypes of nature, this may contain such errors as are inseparable from imperfect observing powers and the finite reason of human beings, whose "knowledge is patchwork," after all. We may, however, derive from such observations much pleasure; they will impart new and unexpected interest to the objects to which they relate, and give to the process of skeletonizing, 
which unmasks the structure of the leaf, a practical and a scientific importance little anticipated by those who have pursued it with an exclusive view to its ornamental and æsthetic results. 
FIG. 2.

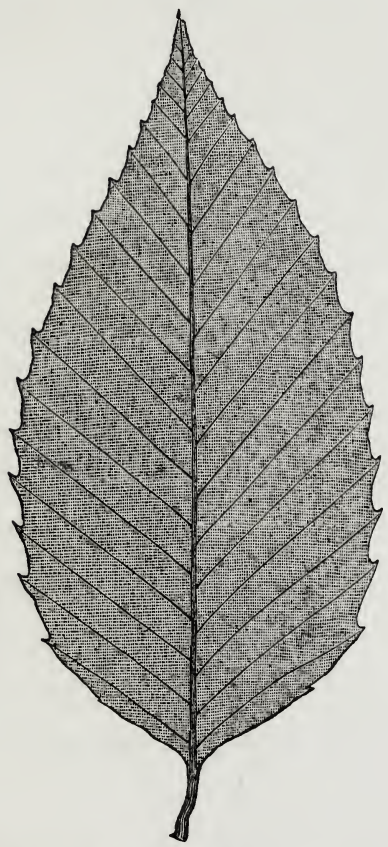

LIAF OF THE BerCe TREx, showing midrib and lateral veins, present in chost exo. genous leaves 



\section{genow and githat to cuntlect.}

Skeletonizing may be out of season when this essay for the first time falls into the hands of the reader; but as soon as the summer foliage has fully expanded in luxuriant variety, the collection of material may commence. It is important that the amateur should make the proper choice of leaves. It will be observed that those which have just opened upon the fresh-grown terminations of the limbs are relatively softer, of a lighter color and more delicate fibre, than those which expanded at the first summons of the spring, in close proximity to the solid woody branches. The little suckers which are apt to grow up from the origin of the roots often bear enormous leaves, but with very little stamina.

Every leaf for our purpose should be fully formed, having attained the firmness belong- 
ing to complete maturity, and should be without a blemish. The punctures made by insects are often fatal to success when every other condition has been fulfilled. In an appendix to this essay, prepared with the aid of Dr. J. Gibbons Hunt, and several ladies of experience in the art, a list is given of those trees the leaves of which we know to have been successfully skeletonized. Almost any or all of our deciduous shade-trees might probably be included; and, variety as well as beauty of form being kept in view, the pretty little leaves of the box, the rose, the pear, and the apple will be as highly prized as those of the larger magnolias, tulip poplars, maples, and lindens.

The lemon, orange, camilla, caoutchouc, and other tropical trees found in our greenhouses, besides being well fitted to the process, have the advantage of being obtainable in the winter, when our own more familiar trees are bare and leafless.

No leaves need be gathered from herbs: 
the organs of these short-lived tenants of the meadow and copse are formed to develop only a succulent stem and soft, flabby leaf, which will soon disappear in the processes we are about to describe, leaving no skeleton to perpetuate their outlines. The variousleaved oaks are unsuited to maceration from a different cause: they have developed underneath their glossy and tough exterior a principle called tannin, which gives to the nut-gall and oak-bark their great commercial value, and which effectually obstructs the decomposition by which we propose to get at the delicate lace-work of the leaves. 


\section{cefaciation.}

THe first step in the process of skeletonizing is to arrange suitable vessels for conducting the maceration. Almost any utensils of wood or earthenware which will hold water will answer the purpose; a single vessel will serve, but there is an advantage in having several, so as to separate the rough calyxes from the tender leaves, and of leaves, to place such as are porous and rapidly decomposable apart from the comparatively tough and unyielding. The specimens are to be covered with soft boiling water, and to be held in place by pieces of glass or other suitable weights, and in the summer placed on a shed or veranda, preferably exposed to the sun during part of the day. A closet near a flue, or some other warm situation, will be better in the winter. Fresh water must be added from time to time, to compen- 
sate for evaporation, but otherwise our rather unsightly and presently offensive mass is best out of sight and out of mind. In four or five weeks the leaves should be examined, and upon those sufficiently softened to admit of cleaning, this somewhat delicate operation may be commenced.

In the case of the ivy, holly, and some other leaves, after maceration the tough skin will peel off from the two faces in separate layers, so as to expose the skeleton covered only by loose parenchyma, which readily washes off. Maples, linden, elm, horse-chestnut, abele, and others, on the contrary, have so slight an epidermis that it soon softens and decays. They require a different treatment; the decayed leaf, being laid smoothly upon a plate or pane of glass, should be swept lightly over with a soft tooth-brush or shaving-brush till cleaned, turning the leaf over at intervals. Sometimes it will be found necessary to return the leaf to the macerating vessel, to complete 
the softening process. Leaves of very lacey and delicate texture may be best cleaned without a brush, by washing thom gently between the thumb and finger under water.

The holly is one of the most difficult leaves to clean. It softens by maceration in from six to twelve weeks, but the skin is very difficult to separate from the hard, thickened edge, and especially from the prickles: a small pair of forceps, used with dexterity, will assist in this operation. When obtained in a perfect condition, this skeleton, like the lemon, japonica, and some others, displays a complete double structure, as though two perfect leaves had been laid one upon the other and grown together at the edges. The leaves of the numerous species of oak, and of hazel and buckthorn, resist the process of maceration so persistently as to induce a resort to other means to obtain their shadowy outlines. 
FIG. 3.

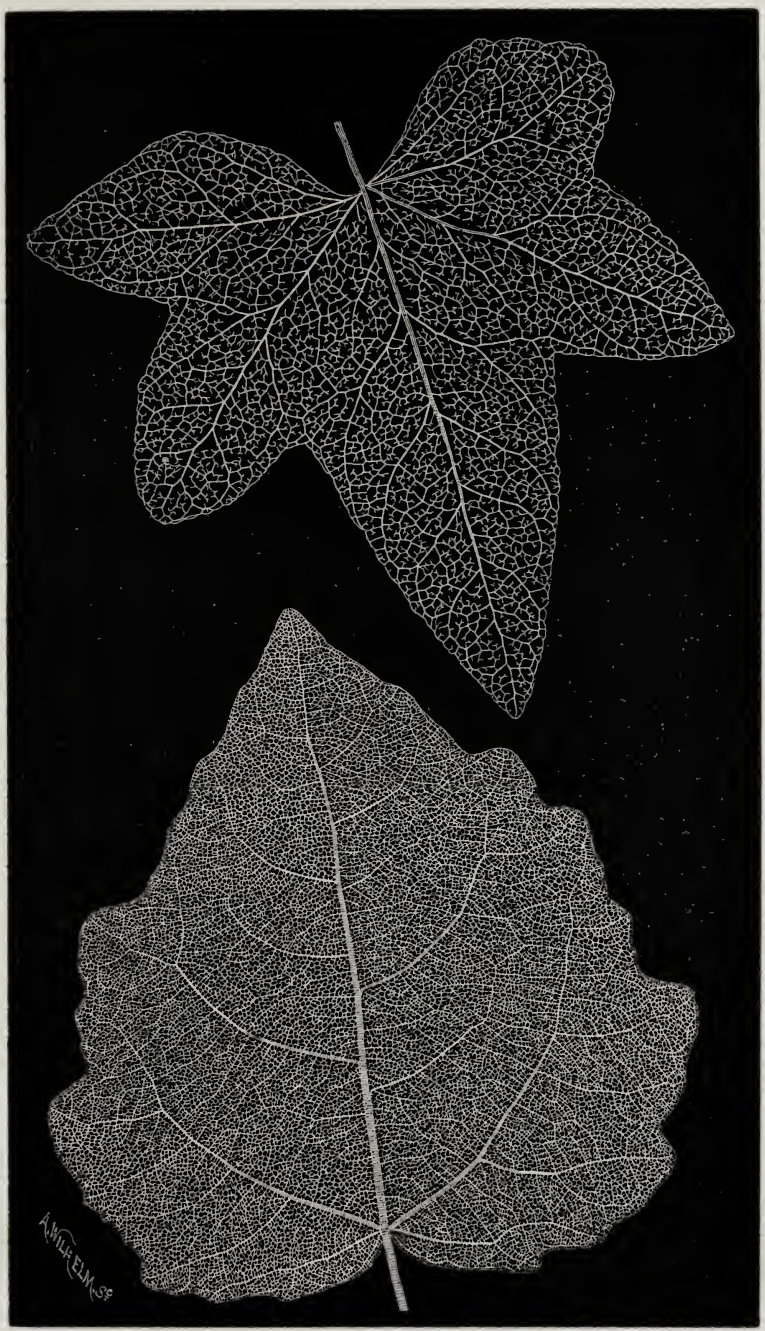

IVY-SILVER FOPLAR 



\section{(1)ther dracesss.}

OnE process, as applied to oaks, consists in flattening out the leaf, previously thoroughly browned and dried by means of a hot sadiron, and then gently tapping over its entire surface with a tolerably soft clothes-brush. If conducted skilfully and thoroughly, this pricking with the sharp bristles will be successful in separating the skin and cellular portions. But skeletons prepared in this way are seldom so delicate or so perfect as those obtained by maceration, and are also so difficult to bleach thoroughly as to be unavailable for grouping with the snow-white products of maceration.

Boiling with soap completely loosens the skin of some leaves, the best instance we have seen being that of a camelia japonica,a beautiful leaf,-the skin of which was blistered over the whole surface, so as to 
peel off with perfect facility, and, by washing under water between the thumb and finger, became a perfect skeleton. No allusion has been made to the use of chemical agents, or the substitution of long boiling for the process of maceration, as applied to leaves generally, because the writer has had but poor success with either, and prefers the slow and sure method already described. 


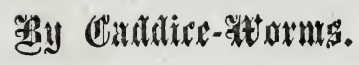

IT yet remains to notice, in connection with oak-leaves, what cannot fail to excite the liveliest pleasure in every naturalist who delights to seek the woods and streams on chill autumn days, though all the fragrant epigeas, the delicate bloodroots, the pale spring beauties, the modest "quaker ladies," and all their lovely spring companions, have so long departed as to diffuse almost a feeling of sadness in visiting the now desolate slopes they rendered so inviting. Let our amateur note what became of the leaves that, having performed their allotted part in the growth of the forest and ceased to be permeated by the life-sustaining sap, have yielded to the blast, and now thickly strew the ground, awakening, as stirred by the wind or the foot of the pedestrian, the familiar rustle of the autumnal woods. These 
are all destined to pass into the earth from which they sprang, by a slow but sure decay. The oak-leaves, as would be supposed, longest resist this destiny. Even those that have fallen into yonder stream have not matted themselves into the slimy mass except by mixing with other and less hardy leaves; and here, if the explorer will search closely, he may occasionally find almost perfectly skeletonized oak-leaves. How came they so? Look: provident nature has found a way to make them, intractable as they are, to subserve a purpose in her wise economy. Thousands of curious little animals, called caddice-bugs, who envelop themselves in a tubular little cocoon of pebbles and sand, are daintily masticating the soft parts of these, leaving all the veinings as perfect as the most captious skeletonizer could desire. It is true that after the rough usage of the running stream upon its pebbled bottom and the thick matrix of twigs, chestnut-burs, acorns, and the like, very few perfect speci- 
mens remain; but then, my friend, here is a hint for us. Change these adverse conditions; colonize, by the aid of an exploring kettle, a few hundred caddices, with their movable tents, to your own sheltered veranda; give them a shallow dish, with a bed of sand in the bottom, and a constant trickle of fresh water to resemble their native stream; then supply them with their favorite leaf, and they will clean it for you to perfection. This has been done successfully, and it can be done again. 


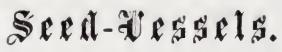

Many mature seed-vessels, and the calyxes of certain flowers, may be skeletonized by maceration or by boiling. These add greatly to the interest and beauty of the phantom case; though it is an obvious fault in most of those prepared in England that they are cumbered with too many large and comparatively opaque objects, at the expense of that airy character which is one of the chief charms of these ornaments. That unsightly weed growing with rank luxuriance on almost every heap of rubbish, especially in the suburbs of all cities,-an opprobrium to both hemispheres, each of the continents disowning its origin, though all know it but too well,-the thorn-apple, or, as we call it in America, from its "discovery" in the vicinity of the first settlement in Virginia, the Jamestown weed, matures a bur in the autumn, a 30 
skeleton of which is present in almost every phantom case I have seen. This should be gathered when it has only slightly opened at the apex, then boiled for some hours or macerated for several weeks, till sufficiently softened, and scrubbed with a tooth-brush under a running stream of water till perfectly cleaned. The seeds are to be removed by shaking, and the cellular structure, called the placenta, pricked out, though without removing the beautiful ligneous structure in which it is embedded. Water should be allowed to run freely through the bur till it is perfectly cleaned, and attention should be given to the external prickles, that every particle of the skin be removed; otherwise, after bleaching, these prominent tips will be less white than the rest. So tough is the ligneous fibre in this bur that it may be freely opened and closed without breaking. it or materially weakening its union with the stem.

Poppy-heads-the pericarps of Papaver 
somniferum-require only about two weeks' maceration. As imported from Turkey and the Levant, they are generally rather large for ordinary phantom cases; but the little heads produced in our gardens are quite delicate and appropriate. The former should be prepared for maceration by removing the seeds through a gimlet-hole in the stem. The delicate lace-work interspersed among the coarser fibres which give it shape is seldom perfectly preserved; but, if a little opening is found necessary in the side, to remove the interior decayed structure, it will occur to every one, in mounting the specimens, to present the fair side to view.

There is great room for experiment in the use of seed-vessels and mature calyxes, the outer floral envelopes, for this ornamental purpose. Some campanulas, mallows, nettles, and scull-caps have already been rendered tributary to it; and in the English cases considerable prominence is given to the graceful bell-shaped calyx of henbane, and of the 


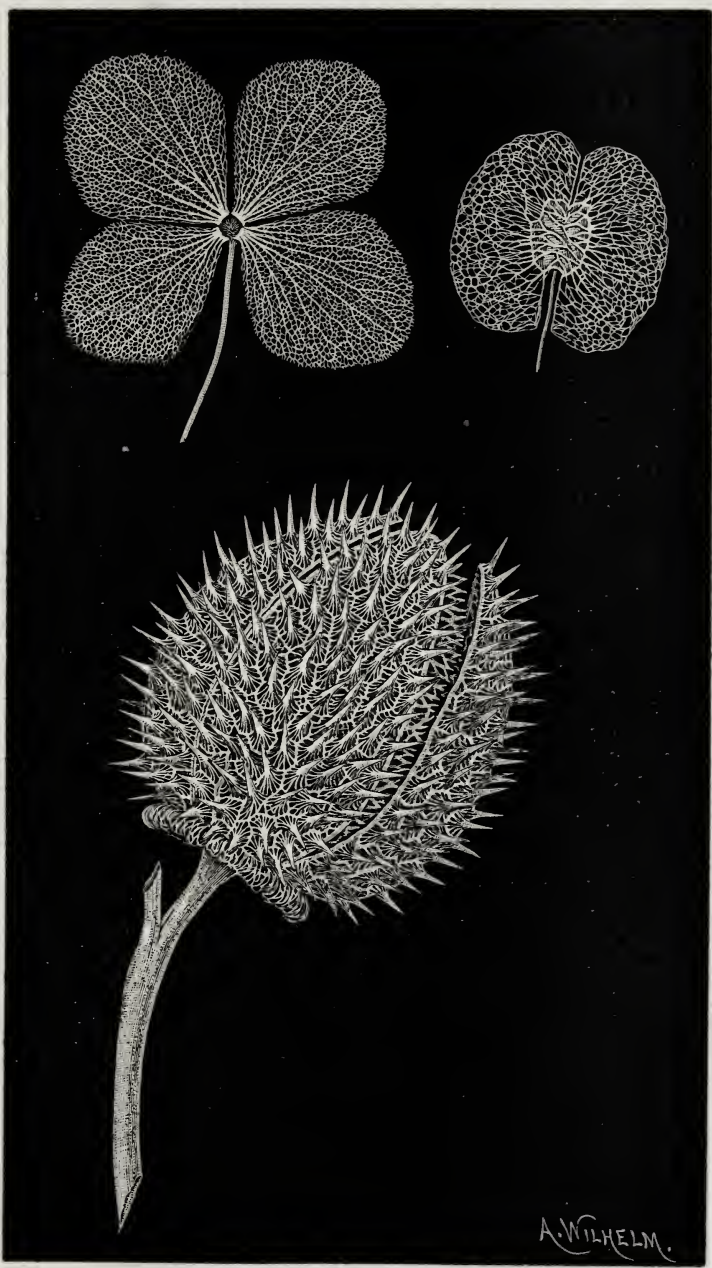

STramontom. 

scarcely less elegant belladonna plants, which, though not naturalized in the United States, are cultivated, and sometimes found growing spontaneously in the neighborhood of botanic gardens. From experience in skeletonizing the inflated calyx of the Nicandra physaloides, or ground cherry, and of a small cultivated species of purple tomato brought to our markets, they can be recommended as furnishing most delicate additions to the phantom case.

The large heads of the common garden hydrangea yield, by maceration, fine preparations, in which each calyx is distinctly and beautifully skeletonized. These are best mounted in little clusters or as single flowers, attached to slender stems, where their extreme lightness can be displayed to the best advantage. 


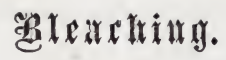

Next to the perfection of the tissues, their perfect whiteness is most important. This is best secured by soaking them in a solution of chloride of lime, which may be made with water alone in a proportion of from one to four ounces of the chloride to the pint. More delicate leaves and calyxes require a weaker solution than that used for the stramonium and poppy-heads: they are to be bleached in a glass or queensware vessel, and removed in a few hours, or as soon as the requisite brilliant whiteness is reached, then washed off with clear water and laid away to be mounted.

Some sprigs of broom-corn, and the delicate petioles or leaf-stalks which have been separated from the leaves in skeletonizing; should also be bleached, as they will be needed subsequently in mounting the specimens.

Some ferns, lycopods, and mosses-espe34 
cially when browned by age or etiolated by the deep shade in which they sometimes groware easily bleached and adapted to occupy conspicuous places in mounted collections. They contain less fibrous structure than the more highly organized leaves used for skeletonizing, and when the green coloring-matter of their cells is completely obliterated, they are so nearly transparent as not to interfere with the airy lightness at which we aim. They are to be bleached in the same solution used for the skeleton leaves, and carefully floated off on to paper, and pressed between the leaves of a book till needed for mounting.

Labarraque's solution, (sometimes called solution of chloride of soda, a preparation occasionally used in medicine and as a disinfectant, is preferred by some for bleaching the skeletons, and, according to my experience, is preferable for ferns, lycopods, or any other vegetable structure in which the green coloring-matter has not been previously removed. This green coloring-matter, called 
by vegetable physiologists chlorophyle, is an organized material, always present in plants grown in the light. Its relations to the life of the plant are not unlike those of the red corpuscles of the blood to that of red-blooded animals. It is hard to destroy this principle by chemical means; and hence, when we desire to bleach a fern or lycopod, as before stated, we shall succeed better after the partial bleaching produced by time and the slow process of drying. Old ferns, brought as relics from places visited long ago, and which have been laid away between the leaves of a book, generally bleach with facility with either of the chlorinated solutions. Some operators are in the habit of macerating ferns for a few days and boiling them occasionally in the water, by which means the chlorophyle appears to be partially decomposed, and bleaching becomes practicable.

As much disappointment is apt to occur to the inexperienced in bleaching, it is necessary to observe the quality of the bleaching- 
materials. Chloride of lime should be dry, or nearly so, and should have a strong chlorinous odor, and care should be taken in dissolving it that it becomes thoroughly incorporated with the water by stirring or trituration. The powder should be poured into the water, not the water on to the powder, and after the solution is made it is to be poured off clear, or filtered, before the skeletons or ferns are introduced. The solution should not be prepared until it is wanted. It is even more important that Labarraque's solution should be fresh and properly prepared; it is a more active bleaching-agent than the solution of chloride of lime. When of good quality, it should be diluted with from four to eight parts of water for bleaching ferns or skeleton leaves, but it is frequently so weak as to require scarcely any dilution. It is always important to remove the preparations as soon as they are perfectly bleached to prevent their becoming too soft and tender. 


\section{gefrounting the specimens.}

Tre information contained in the foregoing pages, besides its general scope, has been specific enough to enable any whose tastes and instincts incline them to attempt skeletonizing to begin with a fair prospect of success. These will naturally desire some hints towards rendering the specimens they have prepared most available for parlorornaments. It will hardly be expected, however, that any attempt should be made to enter into detail on this part of the subject.

The English cases, as before hinted, usually contain too many opaque seed-vessels for our fancy; and many of those arranged in this country seem to have been grouped too compactly, with the aim to display a great variety of objects. Our preference is for a loose, airy-looking arrangement of the leaves, rising at the summit almost to contact with 
the glass under which they are displayed. This glass shade should be abundantly large and of about the same height as its diameter. The cushion that underlies the skeletons, to our taste, may best be of green velvet, re. calling the image of verdure in contrast with frost.

An opened and inverted stramonium-bur, with its tough and hollow stem, may serve as a substantial pedestal for the airy superstrutcture of leaves, while the more solid objects of the collection may be interspersed around and upon its base. One of the most appropriate surmountings is a spray of fine fern, its top curving gracefully under the shade, its fronds slightly pendent as they fall on either side the curved stem.

In a model phantom case, arranged by a medical friend,-himself a model naturalist, "humble that he knows no more,"-a delicate fern, rising to the summit, trembles with electric vibrations on every touch of a silk handkerchief to the glass, while a little tuft 
of hydrangea-flowers, loosed from its moorings, rises to the top, like a balloon, whenever the unseen electric flash is wakened even by dusting the surface of the shade.

Although the usual form of phantom case is that of a bouquet under a glass shade, the fashion has lately obtained of arranging the specimens in an oval frame behind a convex glass. The background may then be of some rich, dark color which displays the white slieleton leaves in strong contrast. $\Lambda$ grouping of seed-vessels at the base of the bouquet allows of the loose ends of the stems being collected and concealed from view; while the leaves and fern-fronds are spread loosely and widely over the enclosed space, allowing an opportunity for the display of taste in their arrangement. The chief objection to this method of displaying the products of the art arises from a deficiency of light, penetrating the recesses of the frame, to give the brilliant effect obtained in the bouquet covered by a transparent shade,-a defect obviated only in part by 
using a very shallow frame with a deeplyconvex glass. When hung against a wall, this should be always placed opposite a window, or in such position as to command the best possible light. It will then form a fitting ornament to the parlor or drawingroom.

Single seed-vessels, as of the poppy, the stramonium, or physalis, or small groupings of these, constitute neat mantel-ornaments. They may be displayed to advantage in a tall wineglass, or a small vase, preferably under a suitable shade. It was the intention to illustrate the mounting of the specimens by appropriate representations of these methods; but the phantom bouquet is too delicate and full of exquisite detail to be well represented in an engraving; and even photography here fails to do justice to objects which to almost microscopic fineness add a lustre nearly approaching transparency. 


\section{destitetics.}

In terming the phantom case a perennial source of enjoyment, we have used an expression fully justified by the fact. In summer, the thoughts it suggests are in strong contrast with our surroundings: its fleecy whiteness recalls the hoar-frost and snow-flakes so pleasantly associated with the season of active exercise and cold and bracing air.

When Sidney Smith conceived the ludicrous notion of solacing himself under the intense heat of the dog-days by laying aside his too cumbrous flesh, that he might sit in his bones, he revelled in a fancy which might well have been suggested by the skeleton case.

On dreary winter days, the bouquet may serve to recall many a happy hour spent among the trees clad in their summer verdure, 
-often, perchance, in companionship which has enhanced the charms of nature, while it beguiled the toil of grateful and congenial pursuit.

Nor is this fair ornament destitute of that highest function of nature and art,-to lift the soul from grovelling things up to the regions of poetry and of love. It displays in a most attractive aspect that union of typical forms with special ends which is everywhere discernible as one of the great initial ideas of the Creator; it fitly illustrates the secret perfections hidden among all the grosser material forms which surround us; and, above all, it is typical of that hidden spiritual outline, obscured by the grossness of the animal nature, but which, through that love which is infinite, may survive the inevitable decay, to shine forever in spotless purity and beauty. 



Fia. 4.

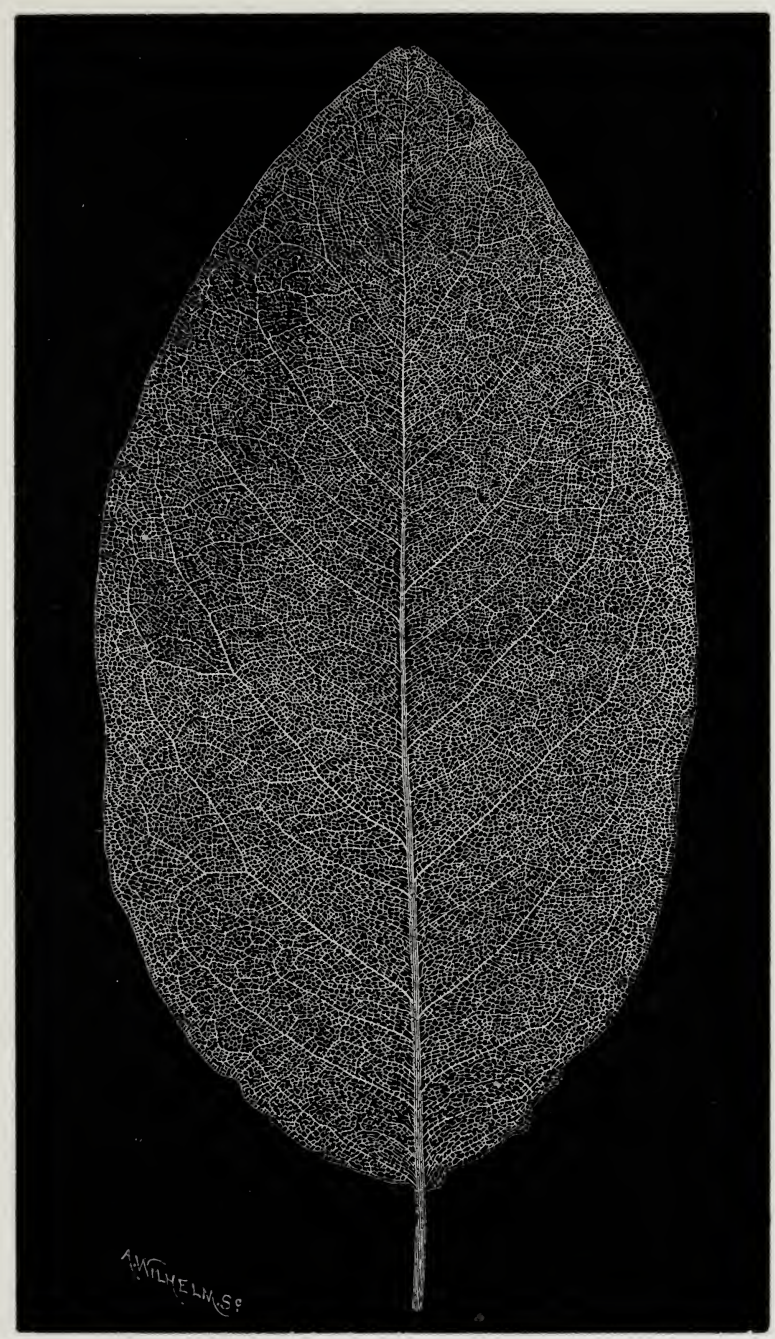

Magnolia Giadca. 



\section{A P P E N D I X.}

LIST. OF TREES, SHRUBS, AND CLIMBERS, THE LEAVES OF WHICH IIAVE BEEN SKELETONIZED BY MACERATION, AND OF SEED-VESSELS USED FOR THE PURPOSES OF THE ART.

\section{I.-Hardy Deciduous Trees and Shrubs.}

Maples-including European sycamore.

Poplars-Lombardy, abele, and aspen.

Lindens-American and European species.

Magnolias-including Magnolia grandiflora.

Tulip Poplar-Liriodendron tulipifera.

WiLlows-probably all the species.

BEECH-Fagus sylvatica, gathered early.

Asir-probably several species.

IICKony - the skeleton splits, in drying.

Chestrut-an open texture, difficult.

Horse-Chestnut-AEsculus hippocastanum.

Eun-Ulmus Americana, "The Treaty Elm."

Kentucky Corfee-Tren-Gymnocladus Canadensis.

Pears-The fruit-bearing, and Pyrus japonica.

Qunde-Tree-Cydonia vulgaris.

Apricor-and probably the plum, with care.

ANDROMEDA-an ornamental dwarf shrub.

DeUTzia - a remarkably beautiful venation.

SPIREA-several cultivated species.

Sassafras-producing various-shaped leaves.

Altina-very difficult to prepare 
Pomegranate-the flowering garden-shrub.

Rose Acacia-Robinia hispida.

RosE-several species, by long maceration.

Medrar-Mespilas japonica.

Wild Cherry-Cerasus serotina.

Sugar-Berry-Celtis occidentalis.

Witch-HAZEL-very desirable: gathered early.

Fraxinella Dictames.

Gardenia Florida.

LaURestina.

Fraxciscea-very handsome.

Erythrina Crystigalea.

Virgilia Lutea.

Wuire Fringe-Tree-Chionanthus Virginica.

\section{II.-Evergreens.}

HoLrr-difficult to prepare, but desirable. Manonia-three species, various forms. BanBerRy-Berberis aristata and purpurea.

Mountain Laurel-Rhododendron.

Box-leaves small, with attractive venation. Butcher's Broom-Ruscus hypophyllum. Olea Fragrans-beautifully serrated. Camelia Japonica-a universal favorite. Caodtcrouc-Fagus elastica, rare.

\section{III.-Vines and Crcepers.}

Ivy-Hedeora helix, various leaves.

Bignonia-evergreen.

Wistaria-Glycena frutescens.

Dutchinas's Pipe-Aristolochia tomentosa.

Grenn Briars-Smilax rotundifolia anll herbacea. WIr.) YAM-Dioscorea villosa. 
IV:-Seed-Vessels, Modified Leaves, and Calyxes which have been used for the Purposes of the Art, prepared chiefly by Maceration, or found naturally Skeletonized.

Tronn-Apple-Jamestown-weed, Datura stramonium.

Poppr-the Levant heads, and cultivated garden-poppies.

MaLLows-several common species.

NICANDRA-Nicandra physaloides.

Physalis-ground-cherry, Physalis viscosa.

Henbane-Hyoscyamus niger-English.

Monk'sHood-Atropa Belladonna-English.

WILd SAGE-calyx; various species of Salvia.

Safflower-False saffron, Carthamus tinctoria.

Canterbury Bells-Campanula medium.

TOAD FLAX-Linaria vulgaris.

Skull-Cap-different species of Scuttelaria.

Fig-Wont-Scrophularia nodosa.

French Tomato-Jerusalem cherry, Solanum pseudo-capsicum.

WiLd Hydrangea-the mature corymb of Hydrangia arborescens.

Hydrangea-the calyx of the ornamental species.

Bladder Sunna-Colutea arborescens.

Bladder-Nut-Staphylea trifolia.

Ptelia-Wild Hop-Ptelia trifoliata.

False Pennyoyal-Isanthus cærulia.

THE ENก. 


$$
1542-835
$$







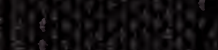

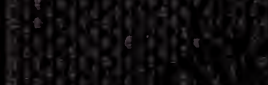

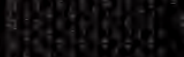

ganging

Minger. 